ORIGINAL RESEARCH ARTICLE

\title{
Medicinal Plants used during Antenatal Care by Pregnant Women in Eastern Uganda
}

DOI: 10.29063/ajrh2017/v21i4.4

Patricia A. Nalumansi ${ }^{l, 2}$, Maud Kamatenesi-Mugisha ${ }^{3}$ and Godwin Anywar ${ }^{4} *$

Department of Science and Technology, International University of East Africa Box 35502 ${ }^{1}$; Department of Environmental Management, College of Agricultural and Environmental Sciences, Makerere University P.O. Box 7062 Kampala, Uganda ${ }^{2}$; Bishop Stuart University, Faculty of Applied Sciences, Mbarara, Uganda, P.O. Box 09³ Department of Plant Sciences Microbiology \& Biotechnology, Makerere University P.O. Box 7062 Kampala, Uganda $^{4}$

*For Correspondence: Email: godwinanywar@gmail.com, ganywar@cns.mak.ac.ug; Phone: +256 702983410

\begin{abstract}
Plants are commonly used during the antenatal stage in pregnancy to manage different ailments in Africa. In Uganda, both medicinal and food plants are used to handle common pregnancy related conditions. An ethnobotanical survey was conducted in Iganga district, eastern Uganda. Seven traditional birth attendants (TBA) and 46 mothers were interviewed. Data was collected using structured questionnaires and household interviews. The TBAs were identified using snowball sampling. A total of 33 plant species, belonging to 23 families were documented. Out of these, the pregnant mothers used $45.5 \%$ as both food and medicine. The most frequently used plant life form was herbs (58.8\%). The leaves are the most commonly used plant parts (59\%). Most of the plants $(58.8 \%)$ were semi cultivated and were being domesticated in crop fields and home gardens. Most of the plants were used to manage anaemia and for child development and good health among the pregnant women. The pregnant women and TBAs in Namungalwe sub County have diverse knowledge on medicinal and nutri-medicinal plants in the management of common pregnancy related diseases, which can be used to supplement modern antenatal services, inspite of the ban of the activities of TBA. Further research on the bioavailability of nutrients, efficacy and safety of the medicinal plants used by pregnant women should be done. (Afr J Reprod Health 2017; 21[4]: 33-44).
\end{abstract}

Keywords: Medicinal Plants, Antenatal, Traditional Birth Attendants, Uganda

\section{Résumé}

Les plantes sont couramment utilisées pendant le stade prénatal pendant la grossesse pour gérer les différentes maladies en Afrique. En Ouganda, les plantes médicinales et alimentaires sont utilisées pour traiter des conditions courantes liées à la grossesse et pour compléter les services de soins prénatals modernes. Une enquête ethnobotanique a été menée dans le district d'Iganga, dans l'est de l'Ouganda. Sept accoucheuses traditionnelles (AT) et 46 mères ont été interviewées. Les données ont été recueillies à l'aide des questionnaires structurés et d'entrevues auprès des ménages. Les AT ont été identifiées en utilisant un échantillonnage en boule de neige. Un total de 33 espèces végétales appartenant à 23 familles ont été documentées. Parmi cellesci, les femmes enceintes consommaient $45,5 \%$ de nourriture et des médicaments. La forme de vie végétale la plus fréquemment utilisée était les herbes $(58,8 \%)$. Les feuilles sont les parties de plantes les plus utilisées (59\%). La plupart des plantes $(58,8 \%)$ étaient semi-cultivées et étaient domestiquées dans les champs cultivés et dans les jardins potagers. La plupart des plantes étaient utilisées pour gérer l'anémie et pour le développement de l'enfant et une bonne santé chez les femmes enceintes. Les femmes enceintes et les accoucheuses traditionnelles dans le sous-comté de Namungalwe avaient des connaissances diverses sur les plantes médicinales et nutri-médicinales dans la prise en charge des maladies courantes liées à la grossesse, qui peuvent être utilisées pour compléter les services prénataux modernes. (Afr J Reprod Health 2017; 21 [4]: 33-44).

Mots-clés: Plantes Médicinales, Prénatale, Accoucheuses Traditionnelles, Ouganda

\section{Introduction}

There is one doctor for every 20,000 people in $\mathrm{Uganda}^{1}$ and 1.3 midwives and nurses per 1,000 people $^{2}$, compared to $200-400$ traditional medical practitioners (TMP) for each person ${ }^{1}$. In contrast, the world health organisation recommends a minimum of 23 doctors, nurses and midwives per 10000 population ${ }^{3}$.

In addition, Uganda has a high a maternal mortality rate of 343 per 100,000 live births ${ }^{4}$. In 
developing countries, up to $80 \%$ of the population use traditional medicine to meet their health care needs ${ }^{5}$. In the rural areas of Uganda close to $90 \%$ of the population have been reported to rely on traditional medicine to meet their day-to day healthcare needs ${ }^{6}$. Women and children constitute the bulk of the people reliant on herbal medicine ${ }^{7,8}$. The broad use of traditional medicine is often attributed to its accessibility and affordability ${ }^{9,10}$.

Traditional birth attendants (TBAs) are important community resource persons who are routinely consulted by pregnant women throughout the course of gestation ${ }^{10}$. Although TBAs mainly operate in the rural areas in developing countries ${ }^{10}$, they also operate in urban areas, and can be an important resource in childbirth care especially among the poor ${ }^{11}$. They assist many women in developing countries to deliver $^{12}$, although no statistics are currently available on their numbers. In Kenya for example, each female TBA attends to more than two hundred pregnant women during the course of their practice ${ }^{10}$.

A large proportion of children in low and middle-income countries are born outside of conventional health facilities, mainly by unskilled community-based birth attendants ${ }^{13}$. However, the issue of TBA has generated a lot of debate and controversy. In some countries, their services have been banned, as is the case in Uganda ${ }^{14}$ and Malawi ${ }^{15}$. Despite the ban on TBAs in Uganda by the Ministry of Health in 2010, $80 \%$ of women in rural areas are still reported to have preference for their services ${ }^{6,14}$ Between $58 \%-80 \%$ of pregnant women in western Uganda deliver outside a health facility with the assistance of TBAs ${ }^{6,16}$.

The TBAs use plant medicines to assist pregnant women to manage disease ${ }^{10}$ such as dizziness, nausea and vomiting among others ${ }^{10,8}$. Medicinal plants play a significant role during pregnancy, birth and postpartum care in many rural areas of the world ${ }^{8,11,17}$. The use of plants to ensure good development of pregnancy and facilitate labour is a well-established practice in Africa ${ }^{18}$.

Although most natural nutritional supplements used during pregnancy have been replaced with synthetic western drugs, many pregnant women still look to natural herbs to provide essential nutrition and to aid in the relief of some common ailments ${ }^{19,20}$. The purpose of this study was to document the medicinal plants and practices of TBAs and pregnant women in eastern Uganda in Namungalwe sub County.

\section{Methods}

\section{Study area}

This study was carried out in the villages of Mwendanfuko, Bulanga and Nabikoote in Namungalwe sub County, Kigulu County, Iganga district. Iganga district is located in south-eastern Uganda between longitudes $33^{\circ} 10^{\prime}$ East and $34^{\circ}$ $00^{\prime}$ East and latitudes $0^{\circ} 06^{\prime}$ North and $1^{\circ} 12^{\prime}$ North and covers an area of $1,039 \mathrm{~km}^{2}$.

\section{The socio-economic status and health care systems}

Most people in Namungalwe belong to the Basoga tribe and are farmers ${ }^{22}$. Health care is provided by both orthodox and traditional health care delivery systems. The orthodox health care delivery system is inadequate ${ }^{22}$ with a doctor to population ratio of 1:41,338 in Iganga district where Namungalwe sub County lies. There is also limited basic equipment in the 16-bed capacity Health Centre III in Namungalwe, serving a population of over 3500 people $^{23}$.

\section{Ethical Considerations}

Prior to any contact with the local community, the study was introduced to the local area authorities through the district administrators. Written prior informed consent was sought from the respondents before interviewing them. Ethical approval for the study was obtained from Makerere University.

Respondents from sixty different households were selected using a systematic random sampling design in three different villages. The first household was selected randomly using the lottery method described in Tefera et al. ${ }^{24}$, and thereafter every third household along a road or 
trail was selected. Data was collected from mothers and TBAs in different households using questionnaires. The respondents were asked what common ailments afflicted pregnant women, what medicinal and nutritional plants they used to manage these ailments, which parts they used and how they were prepared. TBAs were selected using the snowball sampling method ${ }^{25}$

Voucher specimens of plants species mentioned were collected and deposited at the Makerere University herbarium using standard plant collection procedures described in Martin ${ }^{26}$. The scientific names and authorities of the plants were verified using the Kew database at http://www.theplantlist.org on $1^{\text {st }}$ May 2017.

\section{Results}

Fifty-seven respondents aged between 15-50 years were interviewed. Most of the respondents (92\%) were Basoga farmers with low education level. Seven of the respondents were TBAs. Thirty-three plant species from 23 families and 33 genera used in disease management were recorded (Table 1). However, one plant species was not unidentified. Fourteen $(45.5 \%)$ of these plants are used for both nutritional and medicinal purposes. Most species belong to the Malvaceae (4), Anacardiaceae (3), and Asteraceae (3) families. The majority of species used by the pregnant women are semi cultivated $(47.1 \%)$. These are followed by those cultivated $(32.4 \%)$ and the least used are wild $20.6 \%$. The respondents had domesticated many plants like Sida cunefolia, Kigelia africana, and Vernonia amygdalina.

\section{Method of preparation}

The commonest method of preparation of the medicinal plants is boiling in water as a decoction and preparation as accompaniment of staple or sauce. Here, the fresh plant part is picked, washed, and cooked in ground nut/sesame (simsim) paste as vegetable sauce. This is a special preparation only for the pregnant women. Some plant medicines are prepared by steaming such as the
Micrococca mercurialis. The plant leaves are wrapped in a banana leaf, then wrapped along with other staple foods in additional banana leaves and cooked. Fruits of some plant species are eaten as a snack such as $M$. indica. Some plant parts particularly the leaves or whole plants are prepared as an accompaniment of a staple food or as vegetable sauce like A. dubius and Basella alba. For plant medicines that are prepared as herbal teas, a powder of a dried plant part is added to tea and milk like powder from the bark of Steganotaenia araliacea (Table 1).

\section{Key plants used by pregnant women in Eastern Uganda}

The most commonly mentioned plant species were Vernonia amygdalina (39\%) followed by Amaranthus dubius (6\%), Hibiscus sabdarifa (4\%), Dicliptera laxata (4\%) and Persea americana (4\%). Fourteen plants are used to treat more than one ailment; eight of these plants are used to manage more than two conditions. Only two plants Mangifera indica and Corchorus olitarius are used to handle more than three ailments (Table 1).

Seventeen plant species are used in disease management as food and medicine, out of these 15 have the same part used as food and medicine. The other two plants Garcinia buchanaii and Rhus vulgaris have different parts used as food and medicine.

\section{Common ailment categories managed by plant species among pregnant women}

Fourteen $(23.3 \%)$ of medicinal plants were reported to manage lethargy among the pregnant women and thirteen $(21.7 \%)$ of plants are used to manage anaemia, followed by seven (11.7\%) plants used to manage appetite loss and five plants used to boost the body's immunity (Figure 3). All the three ailments viz. lethargy, anaemia and appetite loss managed with most of plants are classified as nutritional disorders by $\mathrm{Cook}^{24}$. Most plants are used to manage more than one disease. 
Table 1: Medicinal Plants Used in the Management of Diseases among Pregnant Women in Eastern Uganda

\begin{tabular}{|c|c|c|c|c|c|c|c|}
\hline Family Name & $\begin{array}{l}\text { Scientific Name, Local Name (Lusoga), } \\
\text { Voucher Number }\end{array}$ & $\mathbf{L F}$ & CS & Conditions treated & FM & PU & Method of Preparation and Administration \\
\hline Acanthaceae & $\begin{array}{l}\text { 1. Dicliptera laxata C. B. Cl., Fuula } \\
\text { (NPK023) }\end{array}$ & $\mathrm{H}$ & $\mathrm{C}$ & $\begin{array}{l}\text { Immunity boosting, } \\
\text { Lethargy, Anaemia }\end{array}$ & 4 & $\mathrm{~L}_{\mathrm{d}}$ & Half tsp boiled, cooled and drunk \\
\hline \multirow[t]{2}{*}{ Amaranthaceae } & $\begin{array}{l}\text { 2. *Amaranthus lividus L. subsp. lividus, } \\
\text { Bugga (NPK102) }\end{array}$ & $\mathrm{H}$ & $\mathrm{C}$ & Lethargy & 1 & $\mathrm{~L}_{\mathrm{f}}$ & $\begin{array}{l}\text { Cooked as vegetable in ground nut paste or steamed } \\
\text { with staple food and eaten }\end{array}$ \\
\hline & $\begin{array}{l}\text { 3. *Amaranthus dubius L. Doodo } \\
\text { (NPK022) }\end{array}$ & $\mathrm{H}$ & $\mathrm{C}$ & $\begin{array}{l}\text { Anaemia, Lethargy, } \\
\text { Appetite loss or } \\
\text { inappetence }\end{array}$ & 6 & $\mathrm{~L}_{\mathrm{f}}$ & $\begin{array}{l}\text { Cooked as a vegetable in ground nut paste or steamed } \\
\text { with staple food and eaten }\end{array}$ \\
\hline \multirow[t]{3}{*}{ Anacardiaceae } & $\begin{array}{l}\text { 4. Rhus vulgaris Meikle, Akakonso } \\
\text { (NPK106) }\end{array}$ & S & $\mathrm{W}$ & Anaemia & 1 & Rt & $\begin{array}{l}\text { Half a tsp of dried powder added to } 500 \mathrm{ml} \text { of tea or } \\
\text { fresh roots boiled for one hour and taken thrice daily }\end{array}$ \\
\hline & $\begin{array}{l}\text { 5. *Anacardium occidentale L., Empelele } \\
\text { (Ebido) (NC) }\end{array}$ & $\mathrm{H}$ & $\mathrm{C}$ & Lethargy & 1 & $\mathrm{Se}$ & Seeds pounded and prepared as a vegetable sauce \\
\hline & $\begin{array}{l}\text { 6. *Mangifera indica L.,Omuyembe } \\
\text { (NPK071) }\end{array}$ & $\mathrm{T}$ & $\mathrm{C} / \mathrm{W}$ & $\begin{array}{l}\text { Immune boosting, } \\
\text { Diarrhoea, Cataract, } \\
\text { Lethargy }\end{array}$ & 2 & $\mathrm{~B}, \mathrm{~L}_{\mathrm{f}}, \mathrm{Fr}$ & $\begin{array}{l}\text { Bark boiled for one hour } \\
\text { Boiled \& drunk } \\
\text { Eaten as snack }\end{array}$ \\
\hline Asclepiadaceae & $\begin{array}{l}\text { 7. Mondia whitei (hook. F.) Skeels, } \\
\text { Mulondo (NPK098) }\end{array}$ & $\mathrm{Cl}$ & $\mathrm{W}$ & Syphilis & 1 & Rt & $\begin{array}{l}\text { Dried and roasted root powder added to tea and taken } \\
2-3 \text { times daily }\end{array}$ \\
\hline \multirow[t]{3}{*}{ Asteraceae } & $\begin{array}{l}\text { 8. Senecio discifolius Oliv., } \\
\text { musuulo, (Mukasa) (NPK015) }\end{array}$ & $\mathrm{H}$ & $\mathrm{C} / \mathrm{W}$ & Vomiting, Anaemia & 1 & $\mathrm{~W}$ & $\begin{array}{l}\text { Whole plant squeezed in water. One tsp taken thrice } \\
\text { daily }\end{array}$ \\
\hline & $\begin{array}{l}\text { 9. Vernonia amygdalina Del., Akabilizi } \\
\text { akatono (NPK109) }\end{array}$ & S & $\mathrm{W}$ & Blocked fallopian tubes & 1 & Rt & $\begin{array}{l}\text { Bark/leaves boiled for one hour. Drink half a mug } \\
\text { twice daily }\end{array}$ \\
\hline & & & & Malaria, Anaemia & 39 & $\mathrm{~L}_{\mathrm{f}}$ & Boiled in water. Half a mug taken 2-3 times daily \\
\hline Asteraceae & 10.Bidens pilosa L. Obukaala, (NPK030) & $\mathrm{H}$ & $\mathrm{C} / \mathrm{W}$ & Anaemia & 2 & $\mathrm{Fr}$ & Tsp of dried fruits boiled and taken as tea \\
\hline Basellaceae & 11.*Basella alba L., Ndelema (NPK088) & $\mathrm{H}$ & $\mathrm{W}$ & Lethargy & 1 & $\mathrm{~L}_{\mathrm{f}}$ & Cooked as a vegetable in ground nut paste \\
\hline Bignoniaceae & $\begin{array}{l}\text { 12.Kigelia africana } \\
\begin{array}{l}\text { Omufungedha } / \\
\text { (NPK028) }\end{array}\end{array}$ & $\mathrm{T}$ & $\mathrm{C} / \mathrm{W}$ & $\begin{array}{l}\text { Syphilis, } \\
\text { Lethargy, } \\
\text { Easy labour }\end{array}$ & 2 & $\mathrm{~L}$ & Half Tsp. boiled and taken as tea \\
\hline
\end{tabular}




\begin{tabular}{|c|c|c|c|c|c|c|c|}
\hline & $\begin{array}{l}\text { 13.Markhamia lutea K. Schum., } \\
\text { Omusambya (NPK088) }\end{array}$ & $\mathrm{T}$ & $\mathrm{W}$ & Blocked fallopian tubes & 1 & $\mathrm{Fl}$ & Boiled and taken as tea \\
\hline Brassicaeae & $\begin{array}{l}\text { 14. *Brassica oleracea L., Capitata } \\
\text { Emboga }(\mathrm{NC})\end{array}$ & $\mathrm{H}$ & $\mathrm{C}$ & Lethargy & 4 & $\mathrm{~L}_{\mathrm{f}}$ & Prepared as a vegetable in ground nut paste \\
\hline \multirow[t]{3}{*}{ Caesalpinioideae } & $\begin{array}{c}\text { 15.Cassia didymbotrya } \\
\text { Muvuvumila (NPK011) }\end{array}$ & S & $\mathrm{C}$ & Inappetence, Yellow fever & 2 & Rt & Boiled for one hour. Half a mug drunk thrice daily \\
\hline & 16.Tylosema fassoglensis (Schweinf.) & $\mathrm{Cl}$ & $\mathrm{W}$ & Anaemia & 2 & Rt & Powder added to cup of tea and taken thrice daily \\
\hline & $\begin{array}{l}\text { Torre and Hillc., Kiyugeyuge } \\
\text { (NPK034) }\end{array}$ & & & Child repositioning & 1 & $\mathrm{~L}_{\mathrm{f}}$ & Prepared in ground nut paste and eaten as sauce \\
\hline Cannabaceae & 17.Cannabis sativa L., Endaye & $\mathrm{H}$ & $\mathrm{C}$ & Measles & 1 & $\mathrm{~L}_{\mathrm{f}}$ & Boiled for one hour. \\
\hline Capparidaceae & $\begin{array}{l}\text { 18. *Cleome gynandra L., Eiyobyo } \\
\text { (NPK083) }\end{array}$ & $\mathrm{H}$ & $\mathrm{C}$ & Lethargy & 1 & $\mathrm{~L}_{\mathrm{f}}$ & $\begin{array}{l}\text { Prepared as a vegetable in ground nut paste and eaten } \\
\text { as sauce }\end{array}$ \\
\hline Clusiaceae & $\begin{array}{l}\text { 19.Garcinia buchananii Bak., Musaali } \\
\text { (NPK069) }\end{array}$ & S & $\mathrm{C} / \mathrm{W}$ & $\begin{array}{l}\text { Vomiting, inappetence, } \\
\text { Dizziness }\end{array}$ & 1 & B & $\begin{array}{l}\text { Dried bark powder is added to a cup of tea or boiled in } \\
\text { milk taken } 3 \text { times a day }\end{array}$ \\
\hline Euphorbiaceae & $\begin{array}{l}\text { 20. *Micrococca mercurialis (L) Benth., } \\
\text { Kalyabakyala (NPK101) }\end{array}$ & $\mathrm{H}$ & $\mathrm{W}$ & Immune boosting & 1 & $\mathrm{~L}_{\mathrm{f}}$ & $\begin{array}{l}\text { Steamed with staple food or squeezed in water and } \\
\text { taken daily }\end{array}$ \\
\hline Fabiaeeae & $\begin{array}{l}\text { 21.Sesbania pachycarpa DC, Lutinda } \\
\text { kyalo (NPK103) }\end{array}$ & $S$ & $\mathrm{C} / \mathrm{W}$ & Stomach pain & 1 & $\mathrm{~L}_{\mathrm{d}}$ & $\begin{array}{l}\text { Added to a cup of tea or fresh leaves are squeezed in } \\
\text { water, and taken as tea }\end{array}$ \\
\hline Lauraceae & $\begin{array}{l}\text { 22. *Persea americana Mill., Fakedo } \\
\text { (NPK037) }\end{array}$ & $\mathrm{T}$ & $\mathrm{C}$ & Anaemia & 4 & $\mathrm{~B} / \mathrm{L}$ & $\begin{array}{l}\text { Boiled for one hour. Half a mug is drunk 2-3 times a } \\
\text { day }\end{array}$ \\
\hline \multirow[t]{4}{*}{ Malvaceae } & $\begin{array}{l}\text { 23. *Abelmoschus esculentus (L.) Moench., } \\
\text { Bamia (NPK090) }\end{array}$ & $\mathrm{H}$ & $\mathrm{C} / \mathrm{W}$ & $\begin{array}{l}\text { Immune } \\
\text { Anaemia }\end{array}$ & 1 & $\mathrm{~L}_{\mathrm{f}}$ & $\begin{array}{l}\text { Cooked as vegetable in groundnut or Sesame paste or } \\
\text { steamed and eaten/ prepared as a herbal bath }\end{array}$ \\
\hline & $\begin{array}{l}\text { 24.Sida cunefolia Robx., Katunga Ngabo } \\
\text { (Kyeyo) (NPK050) }\end{array}$ & $\mathrm{H}$ & $\mathrm{C} / \mathrm{W}$ & Constipation & 1 & $\mathrm{~L}_{\mathrm{f}}$ & Prepared as a vegetable in ground nut paste \\
\hline & $\begin{array}{r}\text { 25.Hibiscus sabdariffa } \\
\text { ekimwifu (NPK008) }\end{array}$ & $\mathrm{H}$ & $\mathrm{C}$ & Anaemia & 4 & $\mathrm{~L}_{\mathrm{f}}$ & $\begin{array}{l}\text { Prepared as a vegetable in groundnut or dried leaf } \\
\text { powder is added to a cup of tea or boiled in milk }\end{array}$ \\
\hline & $\begin{array}{l}\text { 26. * Manihot esculenta crantz, Mwogo } \\
\text { (NPK020) }\end{array}$ & $S$ & $\mathrm{C} / \mathrm{W}$ & Lethargy & 1 & $\mathrm{~L}_{\mathrm{f}}$ & Prepared as a herbal bath and a bath is had twice daily \\
\hline Moraceae & $\begin{array}{l}\text { 27. *Morus alba L. Busokomoli, } \\
\text { (Nkenene) (NPK048) }\end{array}$ & S & $\mathrm{C} / \mathrm{W}$ & $\begin{array}{l}\text { Anaemia, lethargy, } \\
\text { Inappetence }\end{array}$ & 1 & $\mathrm{Fr}$ & Eaten as snack \\
\hline Portulacaceae & $\begin{array}{l}\text { 28.Talinum portulacifolium (Forsik.) } \\
\text { Schweinf, Empoza (NPK014) }\end{array}$ & $\mathrm{H}$ & $\mathrm{C} / \mathrm{W}$ & $\begin{array}{l}\text { Lethargy, } \\
\text { Easy labour }\end{array}$ & 2 & $\mathrm{~L}_{\mathrm{f}}$ & Herbal bath \\
\hline
\end{tabular}




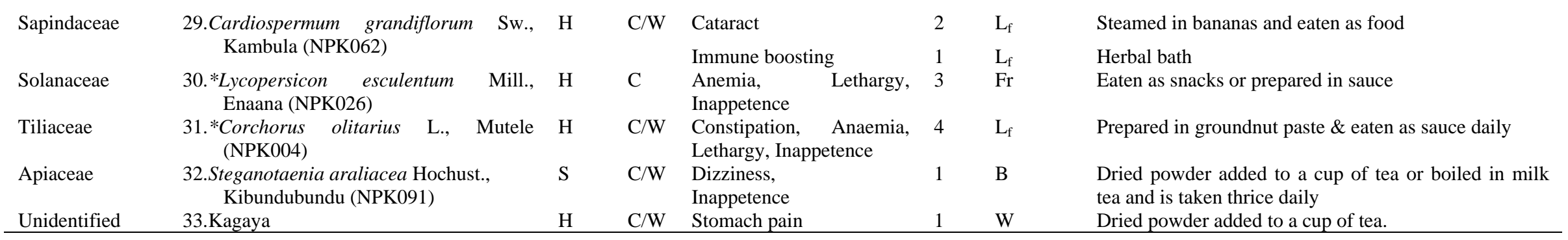

Key: * Plant is nutritional and medicinal; Life form: $\mathrm{H}=$ herb, $\mathrm{S}=$ shrub, $\mathrm{T}=$ tree, $\mathrm{Cl}=$ climber, $\mathrm{Mu}=$ mushroom; Part used: $\mathrm{L}_{\mathrm{f}}=\mathrm{Fresh}$ leaves, $\mathrm{L}_{\mathrm{d}}=\mathrm{Dry}$ leaves), Rt $=$ root, Fr= fruit, $\mathrm{Se}=$ seeds, $\mathrm{B}=$ bark, $\mathrm{Fl}=$ flower, $\mathrm{W}=$ whole; Conservation status: $\mathrm{W}=$ wild; $\mathrm{C}=$ cultivated; $\mathrm{C} / \mathrm{W}=$ semi wild; $\mathbf{N C}=$ not collected, $\mathbf{F M}=$ Frequency of mention

Note: Unless otherwise stated, all the boiling of herbs is done in water. 


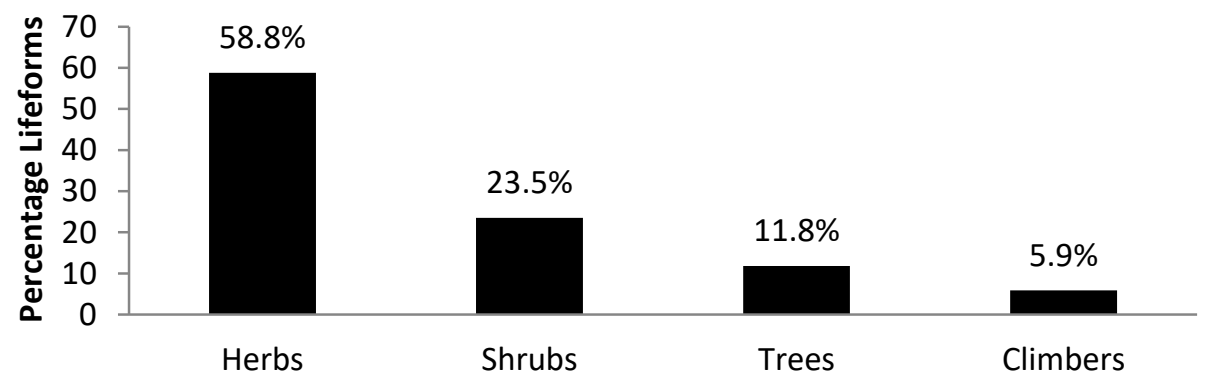

Figure 1: Life Forms of Medicinal Plants Used

Herbs (58.8\%) were the most used plant life forms, while climbers (5.9\%) were the least used life forms (Figure 1).

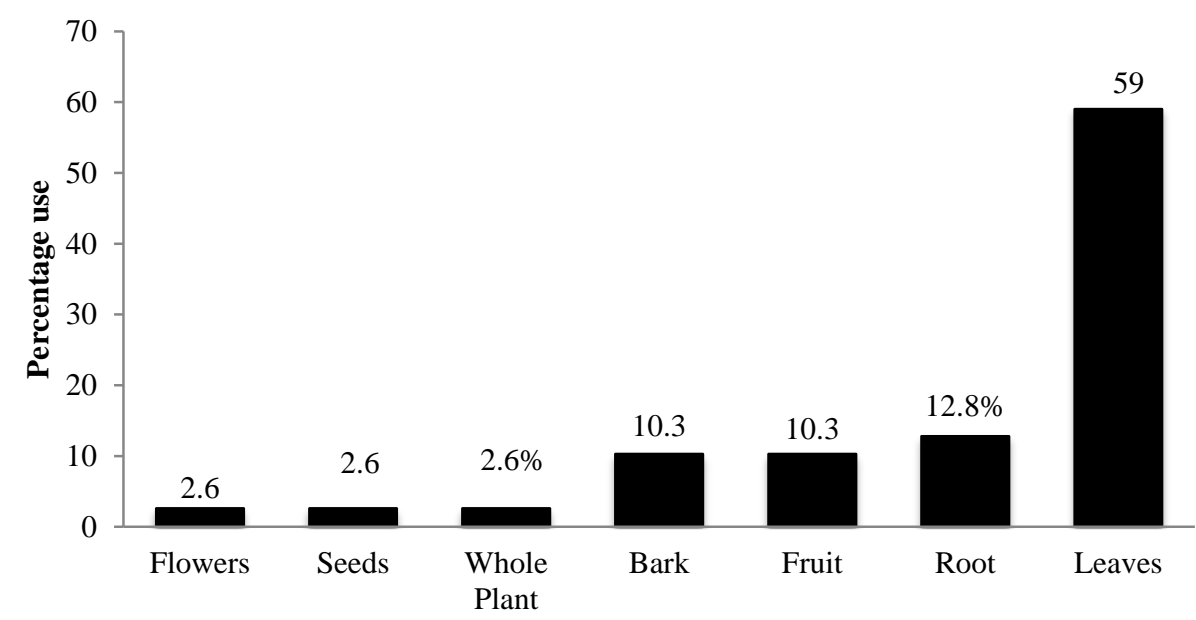

Figure 2: Parts of Plants Used

Leaves are the most commonly used plant parts $(59 \%)$, followed by roots $(12.8 \%)$ and the least used are the flowers $(2.6 \%)$ and seeds $(2.6 \%)$ (Figure 2$)$ 


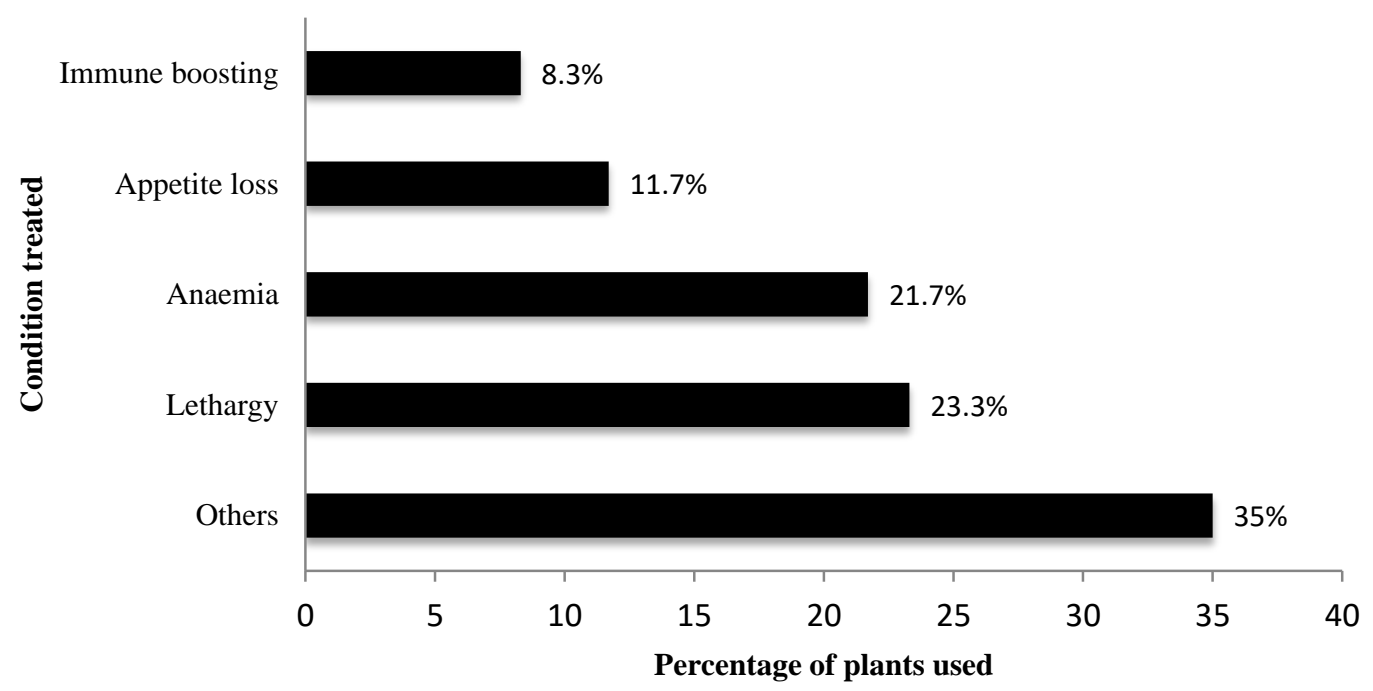

Figure 3: Common Conditions Managed by Plant Species among Pregnant Women in Easter Uganda

\section{Discussion}

The practice of using medicinal plants during pregnancy is still wide spread in Namungalwe, even though the services of TBAs are banned in Uganda. This is not surprising because the ban touches on their livelihoods but does not deal with the underlying reasons for the preference of the services of TBAs, and how best to integrate them. Indeed, studies in other parts of Uganda ${ }^{28-30}$, and African countries such as Malawi ${ }^{15}$ Nigeria $^{31}$ and even $\mathrm{Asia}^{32}$ have reported the preference of TBAs by mothers. Interestingly, even men have been found to actively seek the services of TBAs and utilize them for their wives' healthcare within the community in Uganda ${ }^{29}$. This makes the services of TBAs important in getting men involved in the pregnancy care. The TBAs perform $47-52 \%$ of all deliveries in some remote districts of Uganda ${ }^{33}$. Several reasons have been advanced for this preference, however in one Ugandan $\operatorname{study}^{28}$, the predominant reason reported by both TBAs and pregnant women was verbal and physical abuse by local doctors and nurses.

The use of leaves is a common phenomenon, possibly due to their availability and ease of access as has been shown in various studies in Africa ${ }^{20,8}$. The use of medicinal plants as food and medicine is also practiced elsewhere in pregnant women for example in South Africa ${ }^{18}$ and Côte d'Ivoire ${ }^{34}$. Many wild food plants used for medicinal purposes contain a variety of secondary compounds such as anthocyanins, phenols and antioxidants among others ${ }^{35}$ and essential nutrients, which are useful for both foetal development and mother's health ${ }^{19}$. The domestication of some medicinal plants by TBAs has also been reported in Côte d'Ivoire ${ }^{34}$ and Uganda $^{35}$.

Most of the medicinal plants species documented are used to treat anaemia. Anaemia is also one of the commonest conditions treated with medicinal plants by pregnant women in other African countries, such as Kenya ${ }^{10}$ and Malawi ${ }^{36}$.

The World Health Organisation defined nutritional anaemia as a condition in which the haemoglobin content of the blood is lower than normal as a result of a deficiency of one or more essential nutrients, regardless of the cause of such deficiency ${ }^{38}$. Anaemia in pregnancy is a common problem in most developing countries and a major cause of morbidity and mortality mainly in malaria endemic areas ${ }^{38,39}$. The prevalence of anaemia among pregnant women in sub-Saharan Africa was $46 \%$ in $2011^{39}$. In Uganda, anaemia was the second leading cause of morbidity during 
pregnancy next to malaria ${ }^{39}$, at $34.4 \%$ in $2011^{39}$.

Hibiscus sabdarifa is one of the commonest plant species used in treating anaemia in Uganda. It has positive immonostimulatory effects $^{40,41}$. $H$. sabdariffa significantly increased erythrocyte indices particularly hemoglobin $(\mathrm{Hb})$ concentration and red blood cell count at $2 \mathrm{ml} / \mathrm{kg}$ in rats and the white blood cell count ${ }^{41}$.

Dicliptera laxata is used for treating anaemia among preschool children in eastern Uganda ${ }^{7}$, Cameroon $^{43}$, dysentery in Uganda ${ }^{44}$ and cholorecteral cancer in Kenya ${ }^{45}$. D. laxata has antiinflammatory and antinociceptive activities in vivo $^{45}$.

A. spinosus has been shown to have laxative and bronchodilatory effects in vitro ${ }^{47}$. A. spinosus contains rutin $^{46}$, which is widely acknowledged for its nutraceutical effects and several pharmacological effects $^{48}$ such as antifatigue ${ }^{49}$, immunostimulatory $^{50}$ among others. A. hybridus was shown to be very nutritious containing several vitamins including thiamine, riboflavin, niacin, pyridoxine, ascorbic acid and tocopherol, in addition to 17 amino acids such as isoleucine, leucine, lysine, methionine among others ${ }^{51}$. Amaranthus dubius is also used for anaemic children in Uganda ${ }^{7}$.

Persea americana leaves and bark are used to treat malaria, the bark for diarrhoea and the seeds to stop vomiting and treat anaemia among children below 5 years $^{7}$. P. americana leaves contain antioxidants and quercetin, rutin, luteolin and isorhamnetin $^{52}$.

Vernonia amygadalina leaves are eaten in eastern Uganda $^{53}$ but also used to treat fever, measles, amoebiasis, influenza, convulsions ${ }^{51}$ and stomach ache $^{7}$ Although malaria is one of the commonest diseases encountered during pregnancy, only $V$. amygdalina was reported to treat malaria, despite the large numbers of medicinal plants known for treating malaria throughout Uganda $52, \quad 55 \quad 57$. Although several studies have documented the widespread use of $V$. amygdalina in treating malaria in Africa generally and Uganda specifically $^{7,55-57}$, it is surprising that only one medicinal plant was documented here. However, $V$. amygdalina has been shown to be relatively effective in treating uncomplicated malaria with an associated adequate clinical response (ACR) at day 14 in $67 \%$ of cases in a clinical trial in western Uganda, albeit with complete parasite clearance in only $32 \%$ of those with $\mathrm{ACR}^{55}$. There was also no evidence of significant side effects or toxicity from the medication during the trial. Perhaps this could partly explain the great reliance on $V$. amygdlina for malaria treatment by the pregnant women.

In conclusion pregnant women and TBAs in Namungalwe widely use nutri-medicinal plants in the management of common ailments. These plants are used during pregnancy for both child development and good health among the pregnant women, despite the ban on TBAs. However, further research on the bioavailability of nutrients, efficacy and safety of the medicinal plants used by pregnant women should be done.

\section{Acknowledgements}

We thank Makerere University Directorate of Graduate Research and Training, Carnegie Corporation for funding this research. We are grateful to Prof. Tabuti JRS, the leadership of Namungalwe Sub County for allowing us to conduct this research and TBAs and other respondent for participating in this study.

\section{Authors Contribution}

NAP and KMM participated in designing the protocol of the survey. NAP carried out research; AG participated in data analysis and writing the manuscript. All authors participated in reviewing the manuscript. All authors read and approved the final manuscript.

\section{References}

1. Cross-Cultural Foundation of Uganda (CCFU). Promoting traditional medicine in Uganda: Traditional health practitioners and government working together. Cross-Cultural Foundation of Uganda 2008.

2. World Bank data. Nurses and midwives (per 1,000 people) http://data.worldbank.org/indicator/SH.MED.NUM W.P3?end $=2010 \&$ locations $=$ UG\&start $=2004$ 
Accessed on 21/7/2017 at 20:26 hours

3. World health Organisation: Achieving the health-related MDGs. It takes a workforce! http://www.who.int/hrh/workforce_mdgs/en/ Accessed on 21/7/2017 at 20:26 hours.

4. The World Bank. Maternal mortality ratio (modeled estimate, per 100,000 live births) http://data.worldbank.org/indicator/SH.STA.MMRT ?locations $=$ UG\& view $=$ chart

5. WHO: Traditional Medicine Strategy 2002-2005.

6. Kamatenesi-Mugisha $\mathrm{M}$ and Oryem-Origa H. Medicinal plants used to induce labour during childbirth in western Uganda. Journal of Ethnopharmacology 2006; 109: 1, 1-9

7. Nalumansi P, Kamatenesi-Mugisha M and Anywar G. Medicinal Plants Used in Paediatric Health Care in Namungalwe Sub County, Iganga District, Uganda. Nova Journal of Medical and Biological Sciences 2014; 2(3): 1-14

8. Razafindraibe M, Kuhlman AR, Rabarison $\mathrm{H}$, Rakotoarimanana V, Rajeriarison C, Rakotoarivelo N, Randrianarivony T, Rakotoarivony F, Ludovic R, Randrianasolo A and Bussmann RW. Medicinal plants used by women from Agnalazaha littoral forest (Southeastern Madagascar). Journal of Ethnobiology and Ethnomedicine, 2013 9(1), 73. doi: 10.1186/1746-4269-9-73

9. De Boer H and Lamxay V. Plants Used During Pregnancy, Childbirth and Postpartum Healthcare in Lao PDR: A Comparative Study of the Brou, Saek and Kry Ethnic Groups. Journal of Ethnobiology and Ethnomedicine. 2009; 5:25

10. Kaingu CK, Oduma, JA and Kanui TI. Practices of Traditional Birth Attendants in Machakos District, Kenya. Journal of Ethnopharmacology 2011; 137(1), 495-502. doi: http://dx.doi.org/10.1016/j.jep.2011.05.044

11. Izugbara C, Ezeh A and Fotso JC. The persistence and challenges of homebirths: perspectives of traditional birth attendants in urban Kenya. Health Policy Plan, 2009; 24. doi: 10.1093/heapol/czn042

12. Rudrum S. Traditional Birth Attendants in Rural Northern Uganda: Policy, Practice, and Ethics. Health Care Women Int, 2016; 37(2), 250-269. doi: 10.1080/07399332.2015.1020539

13. Bukar M and Jauro Y. Home births and postnatal practices in Madagali, North-Eastern Nigeria. Nigerian Journal of Clinical Practice 2013; 16(2): 232-237. doi: 10.4103/1119-3077.110151

14. Kabayambi J. Why TBAs are still preferred by pregnant mothers. Uganda Health Communication Alliance (UHCA) in maternal Health. 2015; https://healthuganda.wordpress.com/2015/03/10/wh y-tbas-are-still-preferred-by-pregnant-mothers/ accessed on 11/Jul7/2017 at 18:19 hours EAT

15. Ryan JH, Tang J, Chome N, Hosseinipour M and Hamela G. Why do women deliver with traditional birth attendants and not at health facilities? A qualitative study in Lilongwe, Malawi. Annals of Global Health, 2014; 80(3), 229-230. doi: 10.1016/j.aogh.2014.08.180

16. Kyomuhendo GB. Low use of rural maternity services in Uganda: Impact of women's status, traditional beliefs and limited resources. Reproductive Health Matters, 2003; 11(21): 16-26. doi:http://dx.doi.org/10.1016/S0968-8080(03) 02176-1

17. Kamatenesi MM, Acipa A and Oryem-Origa $\mathrm{H}$. Medicinal plants of Otwal and Ngai Sub Counties in Oyam District, Northern Uganda. Journal of Ethnobiology and Ethnomedicine, 2011; 7:7-7. doi: 10.1186/1746-4269-7-7

18. Van Der Kooi R and Theobald S. Traditional Medicine in Late Pregnancy and Labour: Perceptions of Kgaba Remedies amongst the Tswana in South Africa. African Journal of Traditional, Complementary and Alternative Medicines 2006; 3(1): 11-22.

19. Ssengoba F, Neema S, Mbonye A, Sentubwe O and Onama V. Maternal Health Review Uganda. Makerere University Institute of Public Health, Health System Development Program. 2010: http://www.biomedcentral.com/1472-6882/9/53/ ins2.

20. Fakeye TO, Adisa R and Musa IE. Attitude and Use of Herbal Medicines among Pregnant Women in Nigeria Complementary and Alternative Medicine 2009; 9:53 doi: 10.1186/1472-6882-9-53.

21. Uganda Districts Information Handbook (UDIH) Expanded edition Fountain Publishers, 2012.

22. Namulondo T. Namungalwe Sub County Development Plan 2009.

23. Uganda Bureau of Statistics UBOS (2009) Higher local government statistical abstract Iganga district (2009) http://www.ubos.org/onlinefiles/uploads/ubos/2009 _HLG_\%20Abstract_printed/Iganga\%20District\%2 0statistical\%20abstract\%202009.pdf

24. Tefera E, Belay T, Mekonnen SK, Zeynudin A and Belachew T. Therapeutic efficacy of different brands of albendazole against soil transmitted helminths among students of Mendera Elementary School, Jimma, Southwest Ethiopia. Pan Afr Med J, 2015; 22, 252. doi: 10.11604/pamj.2015.22.252.6501

25. Heckathorn D D. Comment: snowball versus respondentdriven sampling Sociology Methodology 2011; 41(1): 355-366

26. Martin GJ. Ethnobotany: A methods manual. 1995; London: Hall.

27. Cook FEM. Economic Botany Data Collection Standard Prepared For the International Working Group on Taxonomic Database for Plant Sciences (TDWG). Royal Botanical Gardens Kew.1995 http://www.kew.org/tdwguses/

28. Keri L, Kaye D and Sibylle K. Referral practices and 
perceived barriers to timely obstetric care among Ugandan traditional birth attendants (TBA). African Health Sciences, 2010; 10(1): 75-81.

29. Turinawe EB, Rwemisisi JT, Musinguzi LK, de Groot M, Muhangi D, de Vries DH, Mafigiri DK, Katamba A, Parker N and Pool R. Traditional birth attendants (TBAs) as potential agents in promoting male involvement in maternity preparedness: insights from a rural community in Uganda. Reproductive Health, 2016; 13(1): 24. doi: 10.1186/s12978-016-0147-7

30. Yuan ED, Cherukuri AR, Ssembatya R, Naylor MR and DeStigter KK. An Open Conversation with Traditional Birth Attendants in Rural Uganda: The Potential for Collaborative Care. J Glob Radiol. 2017; 3(1): DOI: 10.7191/jgr.2017.1033

31. Imogie AO, Agwubike' EO and Aluko' K. Assessing the Role of Traditional Birth Attendants (TBAs) in Health Care Delivery in Edo State, Nigeria. African Journal of Reproductive Health, 2002; 6(2): 94-100

32. Titaley CR, Hunter CL, Dibley MJ and Heywood P. Why do some women still prefer traditional birth attendants and home delivery?: a qualitative study on delivery care services in west java province, Indonesia. BMC Pregnancy Childbirth, 2010; 10. doi: $10.1186 / 1471-2393-10-43$

33. Uganda Bureau of Statistics (UBOS). Uganda demographic and health survey 2011-2012. Kampala: Government of Uganda; 2013.

34. Malan DF and Neuba DFR. Traditional Practices and Medicinal Plants Use during Pregnancy by AnyiNdenye Women (Eastern Côte d'Ivoire). African Journal of Reproductive Health 2011; 15(1)

35. Anywar G, Oryem-Origa $\mathrm{H}$ and Kamatenesi-Mugisha M. Wild nutriceutical plants from Nebbi district, Uganda. European Journal of medicinal Plants 2014; 4(6): 641-660, DOI: 10.9734/EJMP/2014/7634

36. Maliwichi-Nyirenda CF and Maliwichi LL. Medicinal plants used for contraception and pregnancy related cases in Malawi: A case study of Mulanje District. Journal of Medicinal Plants Research 2010; 4: (20) 2121-2127

37. WHO. Nutritional Anaemias. Technical Report Series No 405. Geneva Switzerland. 1968

38. Korenromp EL, Armstrong-Schellenberg JR, Williams BG, Nahlen BL and Snow RW. Impact of malaria control on childhood anaemia in Africa - a quantitative review. Trop Med Int Health 2004; 9:1050-1065.

39. Stevens GA, Finucane MM, De-Regil LM, Paciorek CJ, Flaxman SR, Branca F, Peña-Rosas JP, Bhutta ZA and Ezzati M Global, regional, and national trends in haemoglobin concentration and prevalence of total and severe anaemia in children and pregnant and non-pregnant women for 1995-2011: a systematic analysis of population-representative data. Lancet Global Health 2011; 1(1), e16-25. doi: 10.1016/s2214-109x(13)70001-9

40. Ministry of Health: National Health Policy Reducing Poverty through Promoting People's Health 2009

41. Otuchristian G, Obasi AN, Omoboyowa AD and Anele PO. Effect of aqueous extract of Hibiscus sabdariffa Calyces on anaemia induced and normal Wistar albino rats. Nigerian Journal of Parasitology 2016; $37(1)$

42. Fakeye TO, Pal A, Bawankule DU and Khanuja SPS. Immunomodulatory effect of extracts of Hibiscus sabdariffa L. (Family Malvaceae) in a mouse model. Phytotherapy Research, 2008; 22(5): 664668. doi: 10.1002/ptr.2370

43. Bayengue SSB, Ndomou M, Mogtomo LMK, Ngane RAN and Tchiegang C. Ethnobotanical survey of medicinal plants used for treating preschool children anemia in an urban setting, DoualaCameroon. African Journal of Plant Science. 2017; 11(5): 160-167

44. Hamill FA, Apio S, Mubira NK, Mosango M, BukenyaZiraba R and Maganyi OW. Traditional herbal drugs of Southern Uganda. J Ethnopharmacol, 2000; 70. doi: 10.1016/s0378-8741(00)00180-

45. Ochwang'i DO, Kimwele CN, Oduma, JA, Gathumbi PK, Mbaria JM and Kiama G. Medicinal plants used in treatment and management of cancer in Kakamega County, Kenya. Journal of Ethnopharmacology, 2014; 151(3): 1040-1055. doi: http://dx.doi.org/10.1016/j.jep.2013.11.051

46. Wolde-Mariam M, Yarlagadda R and Asres K. In vivo anti-inflammatory and antinociceptive activities of the aerial part extract of Dicliptera laxata. Int $J$ Green Pharm 2013; 7(3): 216-23.

47. Chaudhary MA, Imran I, Bashir S, Mehmood MH, Rehman NU and Gilani AH. Evaluation of gut modulatory and bronchodilator activities of Amaranthus spinosus Linn. BMC Complement Altern Med. 2012; 12:166. doi: 10.1186/1472-688212-166

48. Ganeshpurkar A and Saluja AK. The Pharmacological Potential of Rutin. Saudi Pharmaceutical Journal. 2017; 25(2): 149-164. doi: 10.1016/j.jsps.2016.04.025

49. Su KY, Yu CY, Chen YW, Huang YT, Chen CT, Wu HF and Chen YLS. Rutin, a flavonoid and principal component of Saussurea involucrata, attenuates physical fatigue in a forced swimming mouse model. Int. J. Med. Sci. 2014:11 (5): 528-537.

50. Lin JP, Yang JS, Lu CC, Chiang JH, Wu CL, Li JJ, Lin HL, Yang MD, Liu KC, Chiu TH and Chung J. Rutin inhibits the proliferation of murine leukemia WEHI-3 cells in vivo and promotes immune response in vivo. Leuk. Res. 2009; 33 (6): 823-828.

51. Akubugwo IE, Obasi NA, Chinyere GC and Ugbogu AE. Nutritional and chemical value of Amaranthus hybridus L. leaves from Afikpo, Nigeria. African 
Journal of Biotechnology 2007; 6(24)

52. Tabuti JRS, Lye KA and Dhillion SS. Traditional Herbal Drugs of Bulamogi, Uganda: Plants, Use and Administration. Journal of Ethnopharmacology 2003; 88: 19-44

53. Owolabi MA, Coker HAB and Jaja SI. Bioactivity of the phytoconstituents of the leaves of Persea americana Journal of Medicinal Plants Research 2010; 4(12): 1130-1135 DOI: 10.5897/JMPR09.429

54. Tabuti JRS, Dhillion SS and Lye KA. The Status of Wild Food Plants in Bulamogi County, Uganda. International Journal of Food Sciences and Nutrition 2004;(55 (6): 485-498

55. Challand S and Willcox M. A critical trial of the traditional medicine $V$. amygdalina in the treatment of uncomplicated malaria. J Altern Complement Med 2009; 15. doi: 10.1089/acm.2009.009

56. Namukobe J, Kasenene JM, Kiremire BT, Byamukama

R, Kamatenesi-Mugisha M, Krief S, Dumontet V and Kabasa JD.Traditional plants used for medicinal purposes by local communities around the Northern sector of Kibale National Park, Uganda. $J$ Ethnopharmacol, 2011; 136(1): 236-245. doi: 10.1016/j.jep.2011.04.044

57. Adia MM, Anywar G, Byamukama R, Kamatenesi-

Mugisha M, Sekagya Y, Kakudidi E K and Kiremire BT. Medicinal plants used in malaria treatment by Prometra herbalists in Uganda. Journal of Ethnopharmacology, 2014; 155(1): 580-588. doi: http://dx.doi.org/10.1016/j.jep.2014.05.060. 